\title{
PENGARUH PENERAPAN MANAJEMEN RISIKO TERHADAP KINERJA KEUANGAN SEKTOR PERBANKAN PERIODE 2013-2017
}

\author{
Deny Ismanto \\ Universitas Ahmad Dahlan \\ deny.ismanto@mgm.uad.ac.id
}

\begin{abstract}
This study discusses liquidity risk, credit risk, operational risk, and interest rates risk on financial performance at the National Private Foreign Exchange Commercial Bank listed on the Indonesia Stock Exchange for the period 2013-2017. The population in this study was 23 banks. The sampling technique using purposive sampling method, based on research criteria, the samples used in the study were 11 bank. The analysis tool used is panel regression data with eviews 6 . The data used in this study is secondary data obtained from the official website pages of the Indonesia Stock Exchange and Bank Indonesia. Partially, the results of the study indicate that negative liquidity risk to financial performance, negative credit risk to financial performance, negative operational risk to financial performance, and positive interest rates increase to financial performance. Simultaneously liquidity risk, credit risk, operational risk and interest rate risk affect financial performance.
\end{abstract}

Keywords: Financial Performance; Liquidity Risk; Credit Risk; Operational Risk; Interest Rates Risk.

\begin{tabular}{|c|}
\hline PENDAHULUAN \\
\hline $\begin{array}{l}\text { Peran } \text { Perbankan dalam } \\
\text { perekonomian menjadi faktor yang } \\
\text { mendominasi sistem keuangan saat ini, } \\
\text { dianggap peranan perbankan ini sangat } \\
\text { penting untuk membantu memperbaiki dan } \\
\text { menunjang pertumbuhan perekonomian di } \\
\text { suatu negara. Sistem keuangan memegang } \\
\text { peranan penting dalam perekonomian, } \\
\text { sistem keuangan berfungsi mengalokasikan } \\
\text { dana dari pihak yang mengalami surplus } \\
\text { kepada pihak yang mengalami defisit. } \\
\text { Apabila sistem keuangan mengalami } \\
\text { ketidakstabilan, maka pengalokasian dana } \\
\text { akan menjadi salah satu faktor penting yang } \\
\text { menghambat pertumbuhan ekonomi. Hal } \\
\text { ini menunjukkan sistem keuangan yang } \\
\text { tidak stabil, akan berdampak pada } \\
\text { memperburuk kondisi perekonomian, }\end{array}$ \\
\hline
\end{tabular}

terlebih lagi jika sampai mengakibatkan terjadinya krisis, sehingga perbankan yang mengelola kinerjanya dengan baik akan mendorong sistem keuangan yang baik.

$$
\text { Menurut Undang-Undang RI }
$$

Nomor 10 Tahun 1998 tentang perbankan, di Indonesia terdiri dari Bank Umum dan Bank Perkreditan Rakyat (BPR). Pada data statistik perbankan Indonesia bank yang memiliki jumlah aset, jumlah kredit dan penyaluran dana pihak ketiga terbesar ditahun 2018 adalah Bank Umum Swasta Nasional (BUSN) devisa. Jika dilihat dari data perbandingan tahun 2017 dan 2018, BUSN devisa memiliki kenaikan yang cukup besar terkait dengan jumlah aset dan penyaluran dana pihak ketiga. Hal ini dapat menunjukan bahwa bank BUSN devisa sebagai lembaga perantara keuangan (financial intermediaries) memiliki kepercayaan masyarakat yang tinggi. 
Tabel 1. Perkembangan Aset, Jumlah Kredit dan Penyaluran Dana Pihak Ketiga (Miliar Rupiah)

\begin{tabular}{|c|c|c|c|c|c|c|}
\hline \multirow[t]{2}{*}{$\begin{array}{l}\text { Kelompok } \\
\text { Bank }\end{array}$} & \multicolumn{2}{|c|}{ Jumlah Aset } & \multicolumn{2}{|c|}{ Jumlah Kredit } & \multicolumn{2}{|c|}{$\begin{array}{c}\text { Dana Pihak } \\
\text { Ketiga }\end{array}$} \\
\hline & 2017 & 2018 & 2017 & 2018 & 2017 & 2018 \\
\hline $\begin{array}{c}\text { Bank } \\
\text { Persero }\end{array}$ & $\begin{array}{l}2,986,6 \\
17\end{array}$ & $\begin{array}{l}2,985,3 \\
52\end{array}$ & $\begin{array}{l}1,968,4 \\
19\end{array}$ & $\begin{array}{l}1,906,5 \\
43\end{array}$ & $\begin{array}{l}2,213,9 \\
02\end{array}$ & $\begin{array}{l}2,108,7 \\
29\end{array}$ \\
\hline $\begin{array}{l}\text { BUSN } \\
\text { Devisa }\end{array}$ & $\begin{array}{l}2,964,8 \\
55\end{array}$ & $\begin{array}{l}3,012,2 \\
62\end{array}$ & $\begin{array}{l}1,923,2 \\
26\end{array}$ & $\begin{array}{l}1,909,4 \\
90\end{array}$ & $\begin{array}{l}2,222,3 \\
17\end{array}$ & $\begin{array}{l}2,258,3 \\
84\end{array}$ \\
\hline $\begin{array}{c}\text { BUSN Non } \\
\text { Devisa }\end{array}$ & 88,231 & 88,810 & 60,221 & 60,408 & 65,276 & 65,920 \\
\hline BPD & $\begin{array}{l}604,82 \\
0\end{array}$ & $\begin{array}{l}612,85 \\
3\end{array}$ & $\begin{array}{l}393,43 \\
9\end{array}$ & $\begin{array}{l}387,09 \\
3\end{array}$ & $\begin{array}{l}449,38 \\
9\end{array}$ & $\begin{array}{l}483,63 \\
9\end{array}$ \\
\hline $\begin{array}{c}\text { Bank } \\
\text { Campuran }\end{array}$ & $\begin{array}{l}331,73 \\
4\end{array}$ & $\begin{array}{l}341,33 \\
5 \\
\end{array}$ & $\begin{array}{l}225,14 \\
0\end{array}$ & $\begin{array}{l}224,90 \\
8 \\
\end{array}$ & $\begin{array}{l}174,66 \\
0 \\
\end{array}$ & $\begin{array}{l}177,83 \\
1 \\
\end{array}$ \\
\hline Bank Asing & $\begin{array}{l}411,37 \\
6\end{array}$ & $\begin{array}{l}417,83 \\
3\end{array}$ & $\begin{array}{l}211,48 \\
6\end{array}$ & $\begin{array}{l}215,57 \\
8\end{array}$ & $\begin{array}{l}163,83 \\
2\end{array}$ & $\begin{array}{l}160,79 \\
9\end{array}$ \\
\hline
\end{tabular}

Sumber: Statistik Perbankan Indonesia-Vol 16, No 3, Februari 2018

Perkembangan dunia perbankan semakin dilirik oleh berbagai kalangan, tidak menutup kemungkinan suatu perbankan akan terus mengoptimalkan kinerjanya. Berdasarkan dengan upaya melihat dan mengukur kinerja suatu bank, kinerja keuangan dapat diukur dengan rasio profitabilitas. Rasio profitabilitas untuk mengukur kemampuan perusahaan dalam menghasilkan suatu laba dan mengukur manajemen dalam memperoleh keuntungan yang diperoleh dari penjualan dan investasi. Setiap bank memiliki upaya untuk meningkatkan rasio profitabilitas untuk mendapatkan kinerja yang baik. Untuk meningkatkan profitabilitas suatu bank harus mampu menganalisis dan mengelola risiko yang kemungkinan akan terjadi. Upaya bank dalam meninngkatkan profitabilitas dengan menerapkan salah satunya manajemen risiko.

Sektor perbankan di Indonesia menyadari bahwa setiap risiko yang dihadapinya akan berpengaruh pada kinerja perbankan dan tingkat profitabilitas. Manajemen risiko sebagai pendeteksi kerugian yang mungkin terjadi di masa yang akan datang. Risiko yang dinilai terdiri atas 8 (delapan) jenis risiko yaitu risiko kredit, risiko pasar, risiko likuiditas, risiko operasional, risiko hukum, risiko reputasi, risiko stratejik, dan risiko kepatuhan (Otoritas Jasa Keuangan: Surat Edaran No.14/SEOJK.03/2017).
Dengan terjaganya kestabilan sistem keuangan dan kinerja yang baik dari sektor perbankan akan menghasilkan kondisi perekonomian yang baik untuk suatu negara, tentu tidak terlepas dari berbagai risiko yang dihadapi dalam sektor perbankan.

\section{REVIEW LITERATUR DAN HIPOTESIS}

\section{Landasan Teori}

\section{Perbankan}

Menurut Undang-Undang RI Nomor 10 Tahun 1998 tentang Perbankan dalam Kasmir (2013), yang dimaksud dengan Bank adalah "badan usaha yang menghimpun dana dari masyarakat dalam bentuk simpanan dan menyalurkannya kepada masyarakat dalam bentuk kredit dan atau bentukbentuk lainnya dalam rangka meningkatkan taraf hidup rakyat banyak." Kasmir (2013) menambahkan dari pengertian di atas, secara lebih luas lagi bahwa bank merupakan perusahaan yang bergerak dalam bidang keuangan, artinya aktivitas perbankan selalu berkaitan dalam bidang keuangan. Sehingga berbicara mengenai bank tidak terlepas dari masalah keuangan.

Bank adalah suatu badan usaha yang tugas utamanya sebagai lembaga perantara keuangan (financial intermediaries), yang menyalurkan dana dari pihak yang kelebihan dana (idle fund surplus unit) kepada pihak yang membutuhkan dana atau kekurangan dana (deficit unit) pada waktu yang ditentukan (Dendawijaya, 2009). Bank merupakan suatu badan yang berada dalam lembaga keuangan yang menjalankan aktivitas keuangan seperti menghimpun dana dan menyalurkan dana dengan tujuan meningkatkan taraf hidup masyarakat.

Adapun jenis-jenis bank menurut Kasmir (2013), sebagai berikut: 


\section{a. Dilihat Dari Segi Fungsinya}

Menurut Undang-Undang RI Nomor 10 Tahun 1998 tentang perbankan, maka jenis jenis perbankan terdiri dari:

1) Bank Umum

Bank umum adalah bank yang melaksanakan kegiatan usaha secara konvensional dan atau berdasarkan prinsip syariah yang dalam kegiatannya memberikan jasa dalam lalu lintas pembayaran. Sifat jasa yang diberikan adalah umum, dalam arti dapat memberikan seluruh jasa perbankan yang ada. Begitu pula dengan wilayah operasinya dapat dilakukan di seluruh wilayah. Bank umum juga dapat disebut bank komersial (commercial bank).

2) Bank Perkreditan Rakyat (BPR)

Bank Perkreditan Rakyat
(BPR) adalah bank yang
melaksanakan kegiatan usaha
secara konvensional atau
berdasarkan prinsip syariah dalam
kegiatannya tidak memberikan
jasa dalam lalu lintas pembayaran.

\section{b. Dilihat Dari Segi Kepemilikannya}

Menurut Kasmir (2013), ditinjau dari segi kepemilikan maksudnya adalah siapa saja yang memiliki bank tersebut. Kepemilikan ini dapat dilihat dari akte pendirian dan penguasaan saham yang dimiliki bank yang bersangkutan. Jenis bank dilihat dari segi kepemilikan tersebut adalah sebagai berikut:

1) Bank Milik Pemerintah

Dimana baik akte pendirian maupun modalnya dimiliki oleh pemerintah sehingga seluruh keuntungannya adalah milik pemerintah. Contoh bank milik pemerintah dan pemerintah daerah adalah:

a) Bank Negara Indonesia 46 (BNI) b) Bank Rakyat Indonesia (BRI)

c) Bank Tabungan Negara (BTN) Sedangkan bank milik pemerintah daerah (pemda) terdapat di daerah tingkat I dan tingkat II masing-masing provinsi. Sebagai contoh:
a) BPD DKI Jakarta
b) BPD Jawa Barat
c) dan BPD lainnya

2) Bank Swasta Nasional

Bank jenis ini seluruh atau sebagian besar sahamnya dimiliki oleh swasta nasional serta akte pendiriannyapun didirikan oleh swasta, begitu pula pembagian keuntungannya untuk keuntungan swasta pula. Contoh bank swasta nasional antara lain:
a) Bank Muamalat
b) Bank Central Asia
c) Bank Bumi Putra
d) Bank Danamon
e) Bank Duta
f) dan bank swasta lainnya

3) Bank Milik Koperasi

Kepemilikan saham-saham bank ini dimiliki oleh perusahaanperusahaan yang berbadan hukum koperasi. Contoh bank milik koperasi ini adalah bank umum koperasi Indonesia.

4) Bank Milik Asing

Bank jenis ini merupakan cabang dari bank yang ada di luar negeri, baik milik swasta asing maupun milik pemerintah asing. Jelas kepemilikannya adalah oleh pihak luar negeri. Contoh Bank milik asing ini adalah:
a) $\mathrm{ABN}$ AMRON Bank
b) Deutsche Bank
c) Amerika Express Bank
d) Bank of Amerika
e) Bank of Tokyo
f) Bangkok Bank
g) dan bank asing lainnya 
5) Bank Milik Campuran

Kepemilikan saham bank campuran dimilki oleh pihak asing dan pihak swasta nasional. Kepemilikan sahamnya secara mayoritas dimiliki oleh warga Negara Indonesia. Contoh bank campuran ini adalah:
a) Sumitomo Niaga Bank
b) Bank Merincorp
c) Bank Sakura Swadarma
d) dan bank campuran lainnya

\section{c. Dilihat Dari Segi Status}

Menurut Kasmir (2013), bila dilihat dari segi kemampuannya dalam melayani masyarakat, maka bank umum dapat dibagi kedalam dua macam. Kedudukan atau status ini menunjukan ukuran kemampuan bank dalam melayani masyarakat baik dari segi jumlah produk, modal maupun kualitas pelayanannya. Oleh karena itu, untuk memperoleh status tersebut diperlukan penilaianpenilaian dengan kriteria tertentu. Status bank yang dimaksud adalah:

1) Bank Devisa

Merupakan bank yang dapat melaksanakan transaksi ke luar negeri atau yang berhubungan dengan mata uang asing secara keseluruhan, misalnya transfer keluar negeri, inkaso keluar negeri, travelers cheque, pembukaan dan pembayaran letter of credit dan transaksi lainnya. Persyaratanpersayaratan untuk menjadi bank devisa ini ditentukan oleh Bank Indonesia.

2) Bank Non Devisa

Merupakan bank yang belum mempunyai izin untuk melaksanakan transaksi sebagai bank devisa sehingga tidak dapat melaksanakan transaksi seperti bank devisa. Jadi bank non devisa ini melaksanakan transaksi yang dilakukan masih dalam batas-batas negara.

\section{d. Dilihat Dari Segi Cara Menentukan Harga}

Jenis bank dilihat dari segi cara menentukan harga baik harga jual maupun harga beli, terbagi menjadi dalam dua kelompok yaitu:

1) Bank Berdasarkan Prinsip Konvensional

Dalam mencari keuntungan dan menentukan harga kepada para nasabahnya, bank yang berdasarkan prinsip konvensional ini menggunakan dua metode yaitu menetapkan bunga sebagai harga, baik untuk produk simpanan seperti giro, tabungan, maupun deposito dan sistem pengenaan biaya atas jasa-jasa bank lainya.

2) Bank Berdasarkan Prinsip Syariah Bagi bank yang berdasarkan prinsip syariah dalam penetuan harga produknya sangat berbeda dengan bank berdasarkan prinsip konvensional. Bank berdasarkan prinsip syariah adalah aturan perjanjian berdasarkan hukum islam antara bank dengan pihak lain untuk menyimpan dana atau pembiayaan usaha atau kegiatan perbankan lainnya.

\section{Kinerja Keuangan}

Menurut Fahmi (dalam Fitri, 2016), kinerja keuangan adalah suatu analisis yang dilakukan untuk melihat sejauh mana suatu perusahaan telah melaksanakan dengan menggunakan aturan-aturan pelaksanaan keuangan secara baik dan benar. Menurut Jumingan (dalam Fitri, 2016), kinerja keuangan bank merupakan gambaran kondisi keuangan bank pada suatu periode tertentu baik menyangkut aspek penghimpunan dana maupun penyaluran dana yang biasanya diukur dengan 
indikator kecukupan modal, likuiditas dan profitabilitas bank.

Rasio yang digunakan untuk menilai kinerja keuangan yaitu rasio profitabilitas. Rasio profitabilitas merupakan rasio untuk menilai kemampuan perusahaan dalam mencari keuntungan. Penggunaan rasio profitabilitas dapat dilakukan dengan menggunakan perbandingan antara berbagai komponen yang ada di laporan keuangan, terutama laporan keuangan neraca dan laporan laba rugi. Pengukuran dapat dilakukan untuk beberapa periode operasi. Tujuannya adalah agar terlihat perkembangan perusahaan dalam rentang waktu tertentu, baik penurunan atau kenaikan, sekaligus mencari penyebab perubahan tersebut (Kasmir, 2013).

Terkait dengan kinerja keuangan perbankan dalam penelitian ini, maka rasio profitabilitas yang digunakan yaitu ROE ((Return on Equity). ROE adalah rasio untuk mengukur laba bersih sesudah pajak dengan modal sendiri. Rasio ini menunjukan efisiensi penggunaan modal sendiri. Semakin tinggi risiko ini, semakin baik. Artinya posisi perusahaan semakin kuat, semakin pula sebaliknya (Kasmir, 2013).

\section{Manajemen Risiko}

Menurut Hubbart dalam Rustam (2017), manajemen risiko adalah proses indentifikasi, penilaian, dan prioritas risiko yang diikuti oleh koordinasi dan aplikasi sumber daya ekonomi untuk meminimalkan, memantau dan mengawasi kemungkinan terjadinya peristiwa yang tidak menguntungkan.

Penilaian kualitas penerapan manajemen risiko mencerminkan penilaian terhadap kecukupan sistem pengendalian risiko yang mencakup seluruh pilar penerapan manajemen risiko sebagaimana diatur dalam ketentuan otoritas jasa keuangan mengenai penerapan manajemen risiko bagi bank umum. Penilaian kualitas penerapan manajemen risiko bertujuan untuk mengevaluasi efektivitas penerapan manajemen risiko bank sesuai prinsip yang diatur dalam ketentuan otoritas jasa keuangan mengenai penerapan manajemen risiko bagi bank umum. Penerapan manajemen risiko bank sangat bervariasi menurut skala, kompleksitas, dan tingkat risiko yang dapat ditoleransi oleh bank. Dengan demikian, dalam menilai kualitas penerapan manajemen risiko perlu diperhatikan karakteristik dan kompleksitas usaha Bank (Otoritas Jasa Keuangan: Surat Edaran No.14/SEOJK.03/2017).

Penilaian kualitas penerapan manajemen risiko dilakukan terhadap 8 (delapan) jenis risiko yaitu, risiko pasar, risiko likuiditas, risiko kredit risiko operasional, risiko hukum, risiko reputasi, risiko strategis, dan risiko kepatuhan. Dari 8 (delapan) jenis risiko dalam penerapan manajemen risiko, risiko sebagai indikator untuk mengukur kesehatan suatu bank diantaranya risiko pasar, risiko likuiditas, risiko kredit dan risiko operasional. Adapun 8 (delapan) jenis risiko yaitu sebagai berikut:

\section{a. Risiko Likuiditas}

Menurut Fahmi (2014), risiko likuiditas merupakan bentuk risiko yang dialami oleh suatu perusahaan karena ketidakmampuannya dalam memenuhi kewajiban jangka pendeknya, sehingga itu memberi pengaruh kepada terganggunya aktivitas perusahaan ke posisi tidak berjalan secara normal.

Menurut Hanafi (2014), risiko likuiditas terjadi jika perusahaan mengalami kesulitan membayar kewajiban jangka pendek. Jika risiko likuiditas tidak ditangani dengan baik, risiko tersebut bisa meningkat menjadi risiko solvabilitas atau solvency risk, yang bisa mengakibatkan kebangkrutan perusahaan. Risiko likuiditas bank 
bersumber dari sisi aset dan sisi pasiva.

1) Sisi Aset

Jika bank memberikan jaminan atau komitmen untuk memberikan utang sejumlah tertentu dimasa mendatang (misal tiga bulan). Misalkan tiga bulan mendatang calon debitur datang ke bank untuk memanfaatkan janji bank tersebut, maka bank harus bisa menyediakan sejumlah uang yang telah dijanjikan. Jika bank gagal memberikan sejumlah uang tersebut, maka bank menghadapi risiko likuiditas.

2) Sisi Pasiva

Sumber dana bank sebagian besar berasal dari dana pihak ketiga dalam bentuk tabungan dan deposito. Tabungan praktis bisa ditarik setiap saat. Deposito mempunyai jangka waktu yang biasanya cukup pendek (satu bulan sampai satu tahun). Jika penarikan dana oleh masyarakat terjadi lebih besar dari yang diperkirakan, maka bank tersebut bisa menghadapi krisis likuiditas. Jika krisis tersebut tidak ditangani, perusahaan bisa terancam kelangsungannya. Misalkan masyarakat menjadi panik karena tidak bisa mengambil tabungannya, atau muncul rumor tertentu yang tidak baik, masyarakat bisa mengalami krisis kepercayaan terhadap bank tersebut. Sebagai akibatnya, masyarakat akan menarik dananya secara bersamaan dari bank tersebut. Bank bisa jatuh karena sumber dana menghilang, ditarik masyarakat secara bersamaan.

\section{b. Risiko Kredit}

Menurut Hanafi (2016),
risiko kredit terjadi jika
counterparty (pihak lain dalam
transaksi bisnis kita) tidak bisa

memenuhi kewajibannya (wanprestasi). Risiko kredit menjadi semakin penting karena akhir-akhir ini banyak peristiwa gagal bayar yang dialami oleh perusahaan-perusahaan domestik, luar negeri, bahkan Negara sekalipun.

Menurut Fahmi (2014), risiko kredit merupakan bentuk ketidakmampuan suatu perusahaan, institusi, lembaga maupun pribadi dalam menyelesaikan kewajibankewajiban secara tepat waktu baik pada saat jatuh tempo maupun sesudah jatuh tempo dan itu semua sesuai dengan aturan dan kesepakatan yang berlaku. Investor cenderung menempatkan dana ditempat yang mampu memberi kenyamanan dalam bentuk keuntungan dan keamanan. Perbankan menerima mereka yang surplus finansial ini (investor) dengan tanggungjawab memberikan sejumlah keuntungan dalam bentuk bunga dan mengelola dana tersebut dalam bentuk kredit serta mengambil selisih keuntungan sebagai pendapatan perbankan. Hal ini membuat para investor merasakan adanya permasalahan pada saat dana itu ditempatkan, salah satunya disebabkan oleh kredit macet. Maka jika dihubungkan dengan persoalan risiko kredit sudah jelas bahwa keputusan investasi yang berbentuk financial investment sangat memiliki keterkaitan kuat.

\section{c. Risiko Operasional}

Menurut Fahmi (2014), risiko operasional merupakan risiko yang umumnya bersumber dari masalah internal perusahaan, dimana risiko ini terjadi disebabkan oleh lemahnya sistem 
kontrol manajemen yang dilakukan oleh pihak internal perusahaan.

Menurut Dendawijaya (2009), rasio biaya operasional digunakan untuk mengukur tingkat efisiensi dan kemampuan bank dalam melakukan kegiatan operasionalnya. Setiap peningkatan biaya operasional akan berakibat pada berkurangnya laba sebelum pajak yang pada akhirnya akan menurunkan laba atau profitabilitas bank yang bersangkutan.

\section{d. Risiko Pasar}

Menurut Rustam (2017), risiko pasar adalah risiko pada laporan posisi keuangan dan rekening administratif akibat perubahan harga pasar, antara lain risiko berupa perubahan secara keseluruhan dari kondisi pasar, termasuk risiko perubahan harga opsi. Risiko pasar umum dibagi ke dalam empat kategori, yaitu risiko suka bunga, risiko posisi ekuitas, risiko nilai tukar, dan risiko posisi komoditas.

Risiko suku bunga adalah risiko akibat perubahan harga instrumen keuangan dari posisi trading book atau akibat perubahan nilai ekonomis dari posisi banking book yang disebabkan oleh perubahan suku bunga. Tujuan utama manajemen risiko pasar adalah untuk meminimalkan kemungkinan dampak negatif akibat perubahan kondisi pasar terhadap aset dan permodalan perusahaan. Dengan ini, perusahaan diharapkan akan mampu menjaga agar risiko pasar yang diambil perusahaan berada dalam batas yang dapat ditoleransi perusahaan dan perusahaan memiliki modal yang cukup untuk menutup risiko pasar.

\section{e. Risiko Hukum}

Risiko hukum adalah risiko akibat tuntutan hukum dan atau kelemahan aspek yuridis yang dialami suatu perusahaan. Manajemen risiko hukum diperlukan untuk memastikan bahwa proses manajemen risiko dapat meminimalkan kemungkinan dampak negatif dari kelemahan aspek yuridis, ketiadaan dan atau perubahan peraturan perundang-undangan, dan proses litegasi (Rustam, 2017).

\section{f. Risiko Reputasi}

Risiko reputasi adalah risiko akibat menurunya tingkat kepercayaan stakeholder yang bersumber dari persepsi negatif terhadap perusahaan. Risiko reputasi terjadi akibat kejadiankejadian yang merugikan reputasi perusahaan, misalnya pemberitaan negatif di media masa, pelanggaran etika bisnis, dan keluhan nasabah atau hal-hal lain yang bisa menyebabkan risiko reputasi (Rustam, 2017).

\section{g. Risiko Strategis}

Risiko strategis adalah risiko akibat ketidaktepatan dalam pengambilan dan atau pelaksanaan suatu keputusan strategis serta kegagalan dalam mengantisipasi perubahan lingkungan bisnis. Risiko strategis ini bisa timbul antara lain karena kelemahan perusahaan dalam proses formulasi strategi dan ketidaktepatan dalam perumusan strategi, sistem informasi manajemen yang kurang memadai, penetapan tujuan strategis yang terlalu agresif, ketidaktepatan dalam implementasi strategi, dan kegagalan dalam mengantisipasi 
perubahan lingkungan bisnis (Rustam, 2017).

\section{h. Risiko Kepatuhan}

Menurut Rustam (2017), risiko kepatuhan adalah risiko akibat perusahaan tidak memenuhi dan atau tidak melaksanakan peraturan perudangan-undangan dan ketentuan yang berlaku di sebuah Negara. Risiko kepatuhan dapat bersumber dari perilaku hukum, yakni perilaku/aktivitas perusahaan yang menyimpang atau melanggar dari ketentuan atau peraturan perundangan-undangan yang berlaku.

\section{Hipotesis}

\section{Pengaruh Negatif Rasio Likuiditas Terhadap Kinerja Keuangan}

Risiko likuiditas merupakan risiko yang terjadi akibat ketidakmampuannya perusahaan dalam memenuhi kewajiban jangka pendeknya. Sumber dana suatu bank sebagian besar berasal dari dana pihak ketiga dalam bentuk tabungan dan deposito. Jika penarikan dana oleh masyarakat terjadi lebih besar dari yang diperkirakan oleh bank, maka bank tersebut bisa menghadapi krisis likuiditas. Jika krisis tersebut tidak ditangani, perusahaan bisa terancam kelangsungannya. Ketidakmampuan suatu perbankan dalam memenuhi kewajiban jangka pendek akan berdampak pada krisis kepercayaan masyarakat. Sebagai akibatnya, masyarakat akan menarik dananya secara bersamaan dari bank tersebut. Bank bisa jatuh karena sumber dana menghilang, ditarik masyarakat secara bersamaan. Tingginya likuiditas suatu bank dalam hal tersebut menjadi ancaman bagi bank itu sendiri yang berdampak pada kinerja keuangan. Attar (2014) dalam penelitiannya risiko likuditas yang diukur dengan LDR (Loan to Deposit Ratio) berpengaruh negatif tidak signifikan terhadap kinerja keuangan. Berdasarkan uraian di atas, dapat ditarik hipotesis:

$\mathrm{H}_{1}$ : Risiko Likuiditas Berpengaruh Negatif Signifikan Terhadap Kinerja Keuangan Sektor Perbankan Tahun 2013-2017.

\section{Pengaruh Negatif Risiko Kredit Terhadap Kinerja Keuangan.}

Risiko kredit merupakan risiko yang terjadi akibat ketidakmampuan suatu perusahaan dalam memenuhi kewajibannya tepat pada waktu yang telah disepakati. Keputusan investasi dalam hal ini memiliki keterkaitan kuat, karena investor akan mengalirkan dana mereka kepada suatu lembaga atau pihak yang memiliki sistem keamanan dan menguntungkan. Perbankan mendapat aliran dana dari investor dengan tanggungjawab dalam memberikan sejumlah keuntungan dalam bentuk bunga dan mengelola dana tersebut dalam bentuk kredit, serta mengambil selisih keuntungan sebagai pendapatan perbankan. Maka, jika hal ini membuat para investor merasakan adanya permasalahan yang membuat ketidaknyamanan pada saat dana itu ditempatkan, salah satunya disebabkan oleh masalah kredit yang mengakibatkan perusahaan memiliki risiko kredit tinggi. Fitri (2016), dalam penelitiannya risiko kredit yang diukur dengan NPL (Net Performing Loan) menunjukan bahwa penerapan manajemen risiko kredit (NPL) berpengaruh negatif signifikan terhadap kinerja keuangan. Berdasarkan uraian di atas, dapat ditarik hipotesis:

$$
\begin{array}{rlrr}
\mathrm{H}_{2} \text { : } & \text { Risiko } & \text { Kredit } & \text { Berpengaruh } \\
& \text { Negatif } & \text { Signifikan } & \text { Terhadap } \\
& \text { Kinerja } & \text { Keuangan } & \text { Sektor } \\
& \text { Perbankan Tahun 2013-2017. }
\end{array}
$$

\section{Pengaruh Negatif Risiko Operasional Terhadap Kinerja Keuangan.}

Risiko operasional merupakan risiko yang terjadi disebabkan oleh lemahnya sistem manajemen yang 
dilakukan oleh pihak internal perusahaan. Hampir semua risiko yang terjadi disebabkan oleh kegagalan mengelola risiko operasional, karena kaitanya dengan berbagai kesalahan manusia, kegagalan sistem dan kegagalan lainnya yang bersumber dari internal dan eksternal perusahaan. Hal itulah yang menyebabkan semakin tinggi risiko operasional, maka semakin tinggi biaya operasional yang dikeluarkan oleh suatu bank. Hal tersebut akan berakibat pada berkurangnya laba sebelum pajak yang pada akhirnya akan menurunkan laba atau profitabilitas bank yang bersangkutan. Kansil (2017) dalam penelitiannya risiko operasional yang diukur dengan BOPO (Belanja Operasional terhadap Pendapatan Operasional) menunjukan bahwa berpengaruh negatif signifikan terhadap kinerja keuangan. Berdasarkan uraian di atas, dapat ditarik hipotesis:

$\mathrm{H}_{3}$ : Risiko Operasional Berpengaruh Negatif Signifikan Terhadap Kinerja Keuangan Sektor Perbankan Tahun 2013-2017.

\section{Pengaruh Positif Risiko Suku Bunga Terhadap Kinerja Keuangan.}

Risiko suku bunga adalah risiko akibat perubahan harga instrumen keuangan dari posisi trading book atau akibat perubahan nilai ekonomis dari posisi banking book yang disebabkan oleh perubahan suku bunga. Ketika suku bunga meningkat, maka profitabilitas bank juga meningkat, hal ini ditunjukan dengan melihat suku bunga simpanan yang meningkat, maka akan menjadi daya tarik masyarakat untuk menabungkan atau menginvestasikan dananya. Fathunnida (2017) dalam penelitiannya menunjukan bahwa variabel tingkat suku bunga (BI Rate) berpengaruh positif signifikan terhadap kinerja keuangan. Berdasarkan uraian di atas, dapat ditarik hipotesis:

$\mathrm{H}_{4}$ : Risiko Suku Bunga Berpengaruh Positif Signifikan Terhadap Kinerja Keuangan Sektor Perbankan Tahun 2013-2017.

\section{Pengaruh Risiko Likuiditas, Risiko} Kredit, Risiko Operasional, Dan Risiko Suku Bunga Secara Simultan Terhadap Kinerja Keuangan.

$\mathrm{H}_{5}$ : Risiko Likuiditas, Risiko Kredit, Risiko Operasional, Dan Risiko Suku Bunga Secara Simultan Berpengaruh Signifikan Terhadap Kinerja Keuangan Sektor Perbankan Tahun 2013-2017.

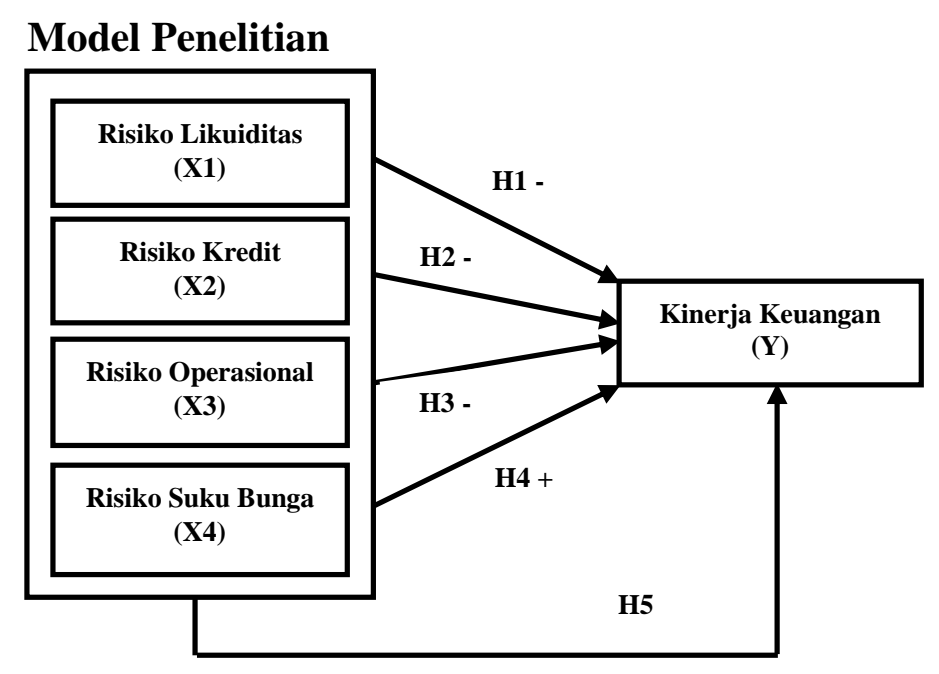

Gambar 1. Model Penelitian

\section{Populasi dan Teknik Pengambilan Sampel}

Populasi adalah wilayah generalisasi yang terdiri atas objek/subjek yang mempunyai kualitas dan karakteristik tertentu yang ditetapkan oleh peneliti untuk dipelajari dan kemudian ditarik kesimpulannya (Sugiyono, 2016). Populasi dalam penelitian ini adalah Bank Umum 
Swasta Nasional (BUSN) devisa yang terdaftar di Bursa Efek Indonesia pada tahun 2013-2017 yang berjumlah 23 bank.

Sugiyono (2016) menjelaskan sampel adalah bagian dari jumlah dan karakteristik yang dimiliki oleh populasi tersebut. Teknik pengambilan sampel yang digunakan dalam penelitian ini adalah metode purposive sampling, yaitu teknik penentuan sampel dengan pertimbangan tertentu. Adapun pertimbangan yang dimaksud disini berupa penentuan sampel berdasarkan kriteria-kriteria tertentu. Kriteria pemilihan sampel dalam penelitian ini, yaitu:

a. Objek yang diteliti yaitu Bank Umum Swasta Nasional (BUSN) devisa yang terdaftar di Bursa Efek Indonesia pada tahun 2013-2017.

b. Bank umum swasta nasional (BUSN) devisa yang menerbitkan laporan keuangan secara lengkap pada periode pengamatan 2013-2017.

c. Kelengkapan data selama penelitian, Jika dalam proses penelitian terdapat perbankan yang tidak memberikan kelengkapan data sehingga tidak dapat dihitung rasionya, maka dalam penelitian akan dikeluarkan dari pemilihan sampel.

Tabel 2. Kriteria Pemilihan Sampel

\begin{tabular}{|c|c|c|}
\hline No & Kriteria & Jumlah \\
\hline 1 & $\begin{array}{lr}\text { Bank umum swasta } \\
\text { nasional } & \text { (BUSN) } \\
\text { devisa yang terdaftar } \\
\text { di Bursa } & \text { Efek } \\
\text { Indonesia pada tahun } \\
\text { 2013-2017. }\end{array}$ & 23 \\
\hline 2 & $\begin{array}{lr}\text { Bank umum } & \text { swasta } \\
\text { nasional } & \text { (BUSN) } \\
\text { devisa yang tidak } & \text { menerbitkan laporan } \\
\text { keuangan } & \text { secara } \\
\text { lengkap pada periode } & \\
\text { 2013-2017. }\end{array}$ & (7) \\
\hline 3 & $\begin{array}{l}\text { Bank umum swasta } \\
\text { nasional (BUSN) } \\
\text { devisa yang tidak } \\
\text { memiliki kelengkapan }\end{array}$ & (5) \\
\hline
\end{tabular}

\begin{tabular}{|l|l|l|}
\hline $\begin{array}{l}\text { data sehingga rasio } \\
\text { tidak dapat dihitung. }\end{array}$ & \\
\hline Jumlah Sampel & $\mathbf{1 1}$ \\
\hline
\end{tabular}

Bardasarkan pada kriteria yang telah ditentukan, maka jumlah sampel dalam penelitian ini tertera pada tabel 3 berikut:

Tabel 3. Daftar Sampel Penelitian

\begin{tabular}{|c|c|l|}
\hline No & Kode & \multicolumn{1}{|c|}{ Nama Bank } \\
\hline 1 & AGRO & $\begin{array}{l}\text { Bank Rakyat Indonesia } \\
\text { Agroniaga }\end{array}$ \\
\hline 2 & BBKP & Bank Bukopin \\
\hline 3 & BBMD & Bank Mestika Dharma \\
\hline 4 & BBNP & $\begin{array}{l}\text { Bank } \\
\text { Parahyangan }\end{array}$ \\
\hline 5 & BMAS & Bank Maspion Indonesia \\
\hline 6 & BNGA & Bank CIMB Niaga \\
\hline 7 & BNII & Bank Maybank Indonesia \\
\hline 8 & BSIM & Bank Sinarmas \\
\hline 9 & NISP & Bank OCBC NISP \\
\hline 10 & BNLI & Bank Permata \\
\hline 11 & MEGA & Bank Mega \\
\hline
\end{tabular}

Sumber: Bursa Efek Indonesia (2020)

\section{Definisi Operasional}

\section{Variabel Independen}

Dalam penelitian ini menggunakan empat variabel independen, yaitu risiko likuiditas yang diproksikan oleh LDR (Loan to Deposit Ratio), risiko kredit yang diproksikan oleh NPL (Net Performing Loan), risiko operasional yang diproksikan oleh BOPO (Belanja Operasional terhadap Pendapatan Operasional) dan risiko suku bunga yang diproksikan oleh (BI 7-Day Repo Rate atau BI Rate). Adapun variabel independen yang digunakan sebagai berikut:

a. LDR (Loan to Deposit Ratio)

Risiko likuiditas yang diukur dengan LDR (Loan to Deposit Ratio). LDR adalah rasio yang memperlihatkan kemampuan bank dalam membayar kembali atau mengembalikan dana dari deposan atas kredit yang diberikannya. LDR dapat dirumuskan sebagai berikut: 
$\mathrm{LDR}=\frac{\text { Jumlah kredit yang diberikan }}{\text { Dana pihak ketiga }}$

b. NPL (Net Performing Loan)

Risiko kredit (Credit Risk) yang diukur dengan NPL ( Net Performing Loan). Semakin tinggi nilai NPL maka semakin tinggi jumlah kredit yang bermasalah, hal ini menyebabkan kondisi suatu perbankan dalam kondisi bermasalah, sehingga akan berdampak pada kinerja keuangan perbankan tersebut. Rasio ini dapat dirumuskan sebagai berikut:

$\mathrm{NPL}=\frac{\text { Kredit Bermasalah }}{\text { Total Kredit }}$

c. BOPO (Belanja Operasional terhadap Pendapatan Operasional)

Risiko operasional yang diukur dengan BOPO (Belanja Operasional terhadap Pendapatan Operasional). Rasio biaya operasional digunakan untuk mengukur tingkat efisiensi dan kemampuan bank dalam melakukan kegiatan operasionalnya (Dendawijaya, 2009). Rasio BOPO yaitu perbandingan antara biaya operasional dan pendapatan operasional. Rasio ini dapat dirumuskan sebagai berikut:

$\mathrm{BOPO}=\frac{\text { Biaya Operasional }}{\text { Pendapatan Operasional }}$

\section{d. BI 7-Day Repo Rate atau BI Rate}

Risiko suku bunga yang diukur dengan BI 7-Day Repo Rate atau BI Rate. Bank Indonesia melakukan penguatan kerangka operasi moneter dengan mengimplementasikan suku bunga acuan atau suku bunga kebijakan baru yaitu BI 7-Day (Reverse) Repo Rate, yang berlaku efektif sejak 19 Agustus 2016, menggantikan BI Rate. Dengan penggunaan instrumen BI 7-Day (Reverse) Repo Rate sebagai suku bunga kebijakan baru, adanya harapan menguatnya sinyal kebijakan moneter dengan suku bunga (Reverse) Repo Rate 7 hari sebagai acuan utama di pasar keuangan dan meningkatnya efektivitas transmisi kebijakan moneter melalui pengaruhnya pada pergerakan suku bunga pasar uang dan suku bunga perbankan.

Risiko suku bunga merupakan risiko yang terjadi akibat perubahan suku bunga yang terjadi di pasar, terkait dengan risiko suku bunga dalam penelitian ini diukur dengan menggunakan BI 7-Day Repo Rate atau BI Rate semakin meningkatnya suku bunga maka profitabilitas bank juga meningkat, hal ini ditunjukan dengan melihat suku bunga simpanan yang meningkat maka akan menjadi daya tarik masyarakat untuk menabungkan atau menginvestasikan dananya, hal tersebut tentu akan berdampak untuk kinerja keuangan perbankan.

\section{Variabel Dependen}

Variabel dependen dalam penelitian ini adalah kinerja keuangan pada sektor perbankan tahun 2013-2017 yang diukur dengan Return On Equity (ROE). ROE adalah perbandingan antara laba bersih bank dengan modal sendiri. ROE dalam penelitian ini merupakan rasio atas laba bersih terhadap modal sendiri pada sektor perbankan yang terdaftar pada sampel penelitian. ROE dapat dirumuskan sebagai berikut:

$($ Return On Equity $)=\frac{\text { Laba Bersih }}{\text { Modal Sendiri }}$

\section{Teknik Analisis Data}

\section{Analisis Asumsi Klasik}

\section{a. Normalitas}

Menurut Widarjono (2013), uji signifikasi pengaruh variable independen terhadap variabel dependen melalui uji t hanya akan valid jika residual yang kita dapatkan 
mempunyai distribusi normal. Ada dua metode yang bisa digunakan untuk mendeteksi nilai residual mempunyai distribusi normal yaitu dengan melalui histogram residual dan uji Jarque-Bera.

Dalam penelitian ini menggunakan metode uji JarqueBera untuk menguji nilai residual. Metode J-B ini didasarkan pada sampel besar yang diasumsikan bersifat asymptotic. Pengambilan keputusan pada uji JB ini yaitu jika nilai probabilitas dari statistik JB lebih besar dari alpha $(\alpha)$, maka data berdistribusi normal.

\section{b. Autokorelasi}

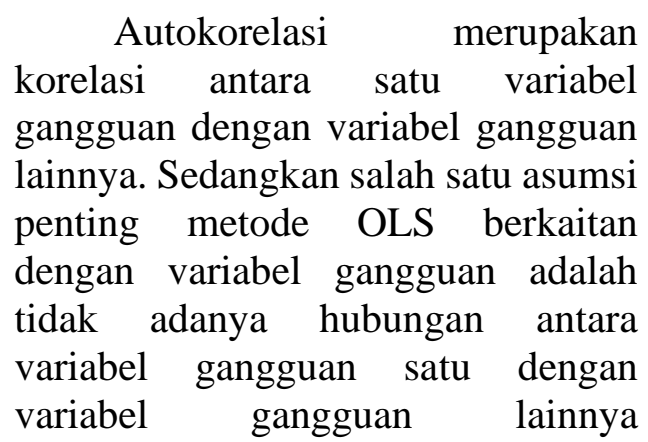
(Widarjono, 2013). Pengujian dugaan terjadinya autokorelasi dapat di uji dengan menggunakan uji BreuschGodfrey. Menurut Kusuma (2012), uji B-G sering juga disebut sebagai uji LM (Lagrange Multiplier). Uji ini dapat menutupi kelemahan pada uji D-W ketika memberikan hasil "tidak ada kesimpulan". Pengambilan keputusan dapat dilakukan sebagai berikut:

Prob. Chi square (p-value) $>0,05(\alpha)$, maka tidak ada autokorelasi

Prob. Chi square (p-value) $<0,05(\alpha)$, maka terjadi autokorelasi

\section{c. Heteroskedastisitas}

Menurut Kusuma (2012), heterokidastisitas adalah kondisi dimana nilai varians error untuk setiap data pengamatan tidak konstan atau var $\left(\mathrm{e}_{\mathrm{i}}\right)=\delta^{2}$. Pada kenyataannya nilai residual sulit memiliki varian konstan, yang membuat nilai taksiran varians dan standar error koefisien regresi menjadi tidak efisien (underestimate) sehingga pengujian hipotesis dengan uji t menjadi tidak valid (overestimate). Untuk mengidentifikasi terjadinya heteroskedastisitas, maka dalam penelitian ini menggunakan uji Breusch Pagan Godfrey (BPG). Pengambilan keputusan dengan menggunakan program Eviews 6 adalah sebagai berikut:

Prob.Chi square (p-value) $>0,05(\alpha)$, maka tidak terjadi heteroskedastisitas.

Prob. Chi square (p-value) $<0,05(\alpha)$, maka terjadi heteroskedastisitas.

\section{d. Multikolinieritas}

Menurut Kusuma (2012), multikolinieritas merupakan salah satu masalah dalam analisis regresi OLS, yang berarti terdapat korelasi atau hubungan yang sangat tinggi di antara variabel independen. Untuk mengidentifikasi terjadinya multikolinieritas, maka penelitian ini melakukan pengujian dengan program Eviews 6 untuk mendeteksi korelasi diantara variabel independen, dengan kesimpulan jika, Prob. (p-value) $<0,05(\alpha)$, maka tidak terjadi multikolinieritas.

Prob. (p-value) > 0,05 $(\alpha)$, maka terjadi multikolinieritas.

\section{Analisis Regresi Data Panel}

Tipe data yang digunakan dalam penelitian ini adalah data panel yang terdiri dari pengabungan antara data time series dan cross section yaitu dari banyak perusahaan yang dijadikan sampel dalam waktu pengamatan beberapa tahun, maka analisis yang digunakan dalam penelitian ini adalah analisis regresi data panel.

Persamaan regresi dalam penelitian ini adalah

$\mathrm{Y}=\alpha+\mathrm{b} 1 \mathrm{X} 1+\mathrm{b} 2 \mathrm{X} 2+\mathrm{b} 3 \mathrm{X} 3+\mathrm{b} 4 \mathrm{X} 4$

Keterangan :

$\alpha=$ Konstanta

b1,b2,b3,b4= Koefisien 


$$
\begin{array}{ll}
\mathrm{Y} & =\text { Kinerja keuangan } \\
\mathrm{X} 1 & =\text { Risiko likuiditas } \\
\mathrm{X} 2 & =\text { Risiko kredit } \\
\mathrm{X} 3 & =\text { Risiko operasional } \\
\mathrm{X} 4 & =\text { Risiko suku bunga }
\end{array}
$$

\section{Uji Hipotesis}

\section{Uji Parsial (Uji T)}

Dalam penelitian ini uji $\mathrm{t}$ (uji parsial) digunakan untuk menguji signifikasi dari masing-masing variabel independen yaitu risiko likuiditas, risiko kredit, risiko operasional dan risiko suku bunga terhadap variabel dependen yaitu kinerja keuangan. Tingkat signifikasi yang digunakan $\alpha=$ 0,05 atau $5 \%$. Jika t hitung $>\mathrm{t}$ tabel, maka hipotesis diterima, dan jika $t$ hitung < t tabel, maka hipotesis ditolak.

\section{Uji Simultan (Uji F)}

Pengujian uji $f$ (uji simultan) digunakan untuk menguji signifikasi variabel independen secara bersamasama yaitu risiko likuiditas, risiko kredit, risiko operasional dan risiko suku bunga terhadap variabel dependen yaitu kinerja keuangan. Tingkat signifikasi yang digunakan $\alpha=0,05$ atau 5\%. Jika $\mathrm{f}$ hitung > f tabel, maka hipotesis diterima, dan jika $\mathrm{f}$ hitung < $\mathrm{f}$ tabel, maka hipotesis ditolak.

\section{Uji Koefisien Determinasi}

Koefisien determinasi $\left(\mathrm{R}^{2}\right)$ adalah koefisien yang menjelaskan hubungan antara variabel dependen (Y) dengan dependen (Y) dalam suatu model. Koefisien determinasi $\left(\mathrm{R}^{2}\right)$ digunakan untuk menjelaskan seberapa besar proporsi varian variabel dependen dijelaskan oleh variabel independen. Nilai koefisiensi determinasi ini terletak antara 0 dan 1 . Pada persamaan regresi linier berganda semakin angkanya mendekati 1 maka semakin baik garis regresi karena mampu menjelaskan data aktualnya. Semakin mendekati angka nol maka kita mempunyai garis regresi yang kurang baik (Widarjono, 2013).

\section{HASIL PENELITIAN DAN PEMBAHASAN}

\section{Hasil Penelitian}

\section{Hasil Uji Asumsi Klasik}

\section{a. Normalitas}

Tabel 4. Hasil Uji Normalitas

\begin{tabular}{|c|c|}
\hline Keterangan & $\begin{array}{c}\text { Prob. Jarque- } \\
\text { Bera }\end{array}$ \\
\hline Uji Jarque-Bera & 0,132398 \\
\hline
\end{tabular}

Berdasarkan hasil uji JarqueBera pada tabel 4 di atas, dapat disimpulkan bahwa data berdistribusi normal. Hal ini ditunjukan dengan nilai probabilitas dari statistik J-B lebih besar dari $\alpha$ yaitu 5\% $(0,132398$ $>0,05)$.

\section{b. Autokorelasi}

Tabel 5. Hasil Uji Autokorelasi

\begin{tabular}{|c|c|}
\hline Keterangan & $\begin{array}{c}\text { Prob. Chi- } \\
\text { Square }\end{array}$ \\
\hline $\begin{array}{c}\text { Uji Breusch- } \\
\text { Godfrey }\end{array}$ & 0,0577 \\
\hline
\end{tabular}

Berdasarkan hasil uji BreuschGodfrey dapat disimpulkan bahwa tidak terjadi masalah autokorelasi, ditunjukan dengan nilai Prob. Chi square ( $p$-value) lebih besar dari $\alpha$ yaitu $5 \%(0,0577>0,05)$.

\section{c. Heteroskedastisitas}

Tabel 6. Hasil Uji

Heteroskedastisitas

\begin{tabular}{|c|c|}
\hline Keterangan & $\begin{array}{c}\text { Prob. Chi- } \\
\text { Square }\end{array}$ \\
\hline Uji Breusch & 0,2168 \\
Pagan Godfrey & \\
\hline
\end{tabular}

Berdasarkan hasil uji BPG pada tabel 6 di atas, dapat disimpulkan bahwa tidak terjadi masalah heterokidastisitas, ditunjukan dengan nilai Prob. Chi square ( $p$-value) lebih besar dari $\alpha$ yaitu $5 \%(0,2168>0,05)$. 


\section{d. Multikolinieritas}

Tabel 7. Hasil Uji Multikolinieritas

\begin{tabular}{|c|c|c|c|c|}
\hline & LDR & NPL & BOPO & BI RATE \\
\hline LDR & 1,000000 & $-0,092290$ & -0207374 & 0,083529 \\
\hline NPL & $-0,092290$ & 1,000000 & 0,627088 & $-0,307873$ \\
\hline BOPO & $-0,207374$ & 0,627088 & 1,000000 & $-0,010103$ \\
\hline BI & 0,083529 & $-0,307873$ & $-0,010103$ & 1,000000 \\
RATE & \multicolumn{4}{|c|}{ Berdasarkan hasil uji } \\
\hline \multicolumn{5}{c}{ multikolinieritas dapat disimpulkan } \\
bahwa tidak terjadi masalah \\
multikolinieritas, ditunjukan dengan \\
nilai korelasi antar variabel \\
independen yang lebih rendah dari \\
0,90 atau 90\%.
\end{tabular}

\section{Hasil Uji Regresi Data Panel} Tabel 8. Hasil Analisis Regresi

\begin{tabular}{|c|c|c|}
\hline Variabel & Coefficient & T-Statistic \\
\hline C & 70,17125 & 11,84956 \\
\hline LDR & $-0,047791$ & 0,913312 \\
\hline NPL & $-0,612191$ & 2,004341 \\
\hline BOPO & $-0,688901$ & 15,32043 \\
\hline BI RATE & 0,590102 & 2,308358 \\
\hline
\end{tabular}

Berdasarkan hasil dari uji regresi data panel model fixed effect maka diperoleh persamaan analisis regresi sebagai berikut:

$$
\begin{array}{llr}
\mathrm{Y}=70,17125 & - & 0,047791 \mathrm{X} 1- \\
0,612191 \mathrm{X} 2 & - & 0,688901 \mathrm{X} 3 \\
+0,590102 \mathrm{X} 4+e . & &
\end{array}
$$

Persamaan analisis regresi tersebut dapat dijelaskan sebagai berikut:

a. Nilai konstanta sebesar 70,17125 artinya apabila tidak ada pengaruh variabel risiko likuiditas (LDR), risiko kredit (NPL), risiko operasional (BOPO) dan risiko suku bunga (BI $R A T E$ ) yang memiliki nilai sama dengan nol, maka nilai konstanta terhadap kinerja keuangan (ROE) adalah sebesar 70,17125.

b. Nilai koefisien regresi untuk variabel risiko likuiditas (LDR) sebesar 0,047791 yang bertanda negatif artinya jika LDR naik 1 satuan maka ROE akan mengalami penurunan sebesar -0,047791 satuan. Dan sebaliknya, apabila nilai LDR turun 1 satuan maka nilai ROE akan mengalami kenaikan sebesar 0,047791 satuan.

c. Nilai koefisien regresi untuk variabel kredit (NPL) sebesar -0,612191 yang bertanda negatif artinya jika NPL naik 1 satuan maka ROE akan mengalami penurunan sebesar 0,612191 satuan. Dan sebaliknya, apabila nilai NPL turun 1 satuan maka nilai ROE akan mengalami kenaikan sebesar -0,612191 satuan.

d. Nilai koefisien regresi untuk variabel risiko operasional (BOPO) sebesar 0,688901 yang bertanda negatif artinya jika BOPO naik 1 satuan maka ROE akan mengalami penurunan sebesar $-0,688901$ satuan. Dan sebaliknya, apabila nilai BOPO turun 1 satuan maka nilai ROE akan mengalami kenaikan sebesar 0,688901 satuan.

e. Nilai koefisien regresi untuk variabel risiko suku bunga (BI RATE) sebesar 0,590102 yang bertanda positif artinya jika BI RATE naik 1 satuan maka ROE akan mengalami kenaikan sebesar 0,590102 satuan. Dan sebaliknya, apabila nilai BI RATE turun 1 satuan maka nilai ROE akan mengalami penurunan sebesar 0,590102 satuan.

\section{Hasil Uji Parsial (Uji T)}

Tabel 9. Hasil Uji Parsial

\begin{tabular}{|l|l|l|l|l|}
\hline Variabel & Koefisien & T-Hitung & $\begin{array}{l}\text { T- } \\
\text { Tabel }\end{array}$ & Ket. \\
\hline LDR & $-0,047791$ & 0,913312 & 1,675 & $\begin{array}{l}\text { Tidak } \\
\text { Signifikan }\end{array}$ \\
\hline NPL & $-0,612191$ & 2,004341 & 1,675 & Signifikan \\
\hline BOPO & $-0,688901$ & 15,32043 & 1,675 & Signifikan \\
\hline $\begin{array}{l}\text { BI } \\
\text { RATE }\end{array}$ & 0,590102 & 2,308358 & 1,675 & Signifikan \\
\hline
\end{tabular}

1) Pengujian variabel risiko likuiditas (X1)

Berdasarkan hasil uji regresi data panel dengan model fixed effect menunjukan nilai koefisien sebesar 0,047791, dengan nilai t-hitung variabel risiko likuiditas sebesar 
0,913312 lebih kecil dari nilai t-tabel yaitu 1,675 , yang artinya variabel risiko likuiditas berpengaruh negatif tidak signifikan, sehingga dapat disimpulkan hipotesis pertama yang menyatakan bahwa risiko likuiditas berpengaruh negatif signifikan terhadap kinerja keuangan pada Bank Umum Swasta Nasional (BUSN) devisa yang terdaftar di Bursa Efek Indonesia pada tahun 2013-2017 ditolak.

2) Pengujian variabel risiko kredit (X2) Berdasarkan hasil uji regresi data panel dengan model fixed effect menunjukan nilai koefisien sebesar 0,612191, dengan nilai t-hitung variabel risiko kredit sebesar 2,004341 lebih besar dari nilai t-tabel yaitu 1,675 , yang artinya variabel risiko kredit berpengaruh negatif signifikan, sehingga dapat disimpulkan hipotesis kedua yang menyatakan bahwa risiko kredit berpengaruh negatif signifikan terhadap kinerja keuangan pada Bank Umum Swasta Nasional (BUSN) devisa yang terdaftar di Bursa Efek Indonesia pada tahun 2013-2017 diterima.

3) Pengujian variabel risiko operasional (X3)

Berdasarkan hasil uji regresi data panel dengan model fixed effect menunjukan nilai koefisien sebesar 0,688901 , dengan nilai t-hitung variabel risiko operasional sebesar 15,32043 lebih besar dari nilai t-tabel yaitu 1,675 , yang artinya variabel risiko operasional berpengaruh negatif signifikan, sehingga dapat disimpulkan hipotesis ketiga yang menyatakan bahwa risiko operasional berpengaruh negatif signifikan terhadap kinerja keuangan pada Bank Umum Swasta Nasional (BUSN) devisa yang terdaftar di Bursa Efek Indonesia pada tahun 2013-2017 diterima.
4) Pengujian variabel risiko suku bunga (X4)

Berdasarkan hasil uji regresi data panel dengan model fixed effect menunjukan nilai koefisien sebesar 0,590102, dengan nilai t-hitung variabel risiko suku bunga sebesar 2,308358 lebih besar dari nilai t-tabel yaitu 1,675 , yang artinya variabel risiko suku bunga berpengaruh positif signifikan, sehingga dapat disimpulkan hipotesis keempat yang menyatakan bahwa risiko suku bunga berpengaruh positif signifikan terhadap kinerja keuangan pada Bank Umum Swasta Nasional (BUSN) devisa yang terdaftar di Bursa Efek Indonesia pada tahun 2013-2017 diterima.

\section{Hasil Uji Simultan (Uji F)}

Tabel 10. Hasil Uji Simultan

\begin{tabular}{|c|c|c|c|}
\hline N & F-Hitung & $\begin{array}{c}\text { F- } \\
\text { Tabel }\end{array}$ & Ket. \\
\hline 55 & 79,09323 & 2,79 & Signifikan \\
\hline
\end{tabular}

Berdasarkan hasil uji secara simultan pada tabel 10 di atas, menunjukan nilai f-hitung sebesar 79,09323, yang mana lebih besar dari nilai f-tabel yaitu 2,79. Artinya variabel risiko likuiditas, risiko kredit, risiko operasional dan risiko suku bunga secara simultan berpengaruh signifikan, sehingga dapat disimpulkan hipotesis kelima yang menyatakan bahwa variabel risiko likuiditas, risiko kredit, risiko operasional dan risiko suku bunga secara simultan berpengaruh signifikan terhadap kinerja keuangan pada Bank Umum Swasta Nasional (BUSN) devisa yang terdaftar di Bursa Efek Indonesia pada tahun 2013-2017 diterima.

\section{Hasil Uji Koefisien Determinasi Tabel 11. Hasil Uji Koefisien} Determinasi

\begin{tabular}{|c|c|}
\hline $\mathrm{N}$ & R-Squared \\
\hline 55 & 0,965136 \\
\hline
\end{tabular}


Berdasarkan hasil uji koefisien determintasi di atas, menunjukan nilai $R$ Square sebesar 0,965136 atau 96,51\%, yang artinya variabel kinerja keuangan dapat dijelaskan oleh variabel independen yaitu risiko likuiditas, risiko kredit, risiko operasional dan risiko suku bunga sebesar 96,51\%, sedangkan $3,49 \%$ dijelaskan oleh variabel-variabel lainnya yang tidak diteliti dalam penelitian ini.

\section{Pembahasan}

\section{Pengaruh Negatif Risiko Likuiditas (LDR) Terhadap Kinerja Keuangan (ROE).}

Berdasarkan hasil uji di atas, dapat diperoleh nilai koefisien sebesar 0,047791 dan nilai t-hitung lebih kecil dari t-tabel 1,675 $(0,913312<1,675)$. Artinya risiko likuiditas berpengaruh negatif tidak signifikan terhadap kinerja keuangan sektor perbankan periode 2013-2017. Hipotesis pertama yang mengatakan risiko likuiditas berpengaruh negatif signifikan terhadap kinerja keuangan sektor perbankan periode 2013-2017 ditolak.

Peraturan Bank Indonesia No.19/6/PBI/2017 menyatakan bahwa LDR merupakan rasio kredit yang diberikan kepada pihak ketiga dan memenuhi persayaratan tertentu untuk diterbitkan oleh bank agar memperoleh pendanaan. LDR yang tinggi menunjukkan profitabilitas yang besar, karena kredit yang disalurkan oleh bank berjalan dengan efektif. Berdasarkan penelitian sebelumnya yang dilakukan Sofyan (2016) menunjukkan bahwa LDR berpengaruh positif terhadap ROE.

\section{Pengaruh Negatif Risiko Kredit (NPL) Terhadap Kinerja Keuangan (ROE).}

Berdasarkan hasil uji di atas, dapat diperoleh nilai koefisien sebesar 0,612191 dan nilai t-hitung lebih kecil dari t-tabel 2,004341 (2,004341 > 1,675). Artinya risiko kerdit berpengaruh negatif signifikan terhadap kinerja keuangan sektor perbankan periode 2013-2017. Hipotesis kedua yang mengatakan risiko kredit berpengaruh negatif signifikan terhadap kinerja keuangan sektor perbankan periode 2013-2017 diterima.

Risiko kredit merupakan risiko yang terjadi akibat ketidakmampuan suatu perusahaan dalam memenuhi kewajibannya tepat pada waktu yang telah disepakati. Keputusan investasi dalam hal ini memiliki keterkaitan kuat, karena investor akan mengalirkan dana mereka kepada suatu lembaga atau pihak yang memiliki sistem keamanan dan menguntungkan. Perbankan mendapat aliran dana dari investor dengan tanggungjawab dalam memberikan sejumlah keuntungan dalam bentuk bunga dan mengelola dana tersebut dalam bentuk kredit, serta mengambil selisih keuntungan sebagai pendapatan perbankan.

Sebuah bank yang dirongrong oleh kredit bermasalah dalam jumlah besar, akan cenderung menurunkan profitabilitasnya (Aldrigde, 2008). Hal tersebut akan membuat para investor merasakan adanya permasalahan yang membuat ketidaknyamanan pada saat dana itu ditempatkan, salah satunya disebabkan oleh masalah kredit yang mengakibatkan perusahaan memiliki risiko kredit tinggi. Fitri (2016), dalam penelitiannya risiko kredit yang diukur dengan NPL (Net Performing Loan) menunjukan bahwa penerapan manajemen risiko kredit (NPL) berpengaruh negatif signifikan terhadap kinerja keuangan.

\section{Pengaruh Negatif Risiko Operasional (BOPO) Terhadap Kinerja Keuangan (ROE).}

Berdasarkan hasil uji di atas, dapat diperoleh nilai koefisien sebesar - 
0,688901 dan nilai t-hitung lebih kecil dari t-tabel 15,32043 (15,32043 > 1,675). Artinya risiko operasional berpengaruh negatif signifikan terhadap kinerja keuangan sektor perbankan periode 2013-2017. Hipotesis ketiga yang mengatakan risiko operasional berpengaruh negatif signifikan terhadap kinerja keuangan sektor perbankan periode 2013-2017 diterima.

Risiko operasional merupakan risiko yang terjadi disebabkan oleh lemahnya sistem manajemen yang dilakukan oleh pihak internal perusahaan. Hampir semua risiko yang terjadi disebabkan oleh kegagalan mengelola risiko operasional, karena kaitanya dengan berbagai kesalahan manusia, kegagalan sistem dan kegagalan lainnya yang bersumber dari internal dan eksternal perusahaan. Hal itulah yang menyebabkan semakin tinggi risiko operasional, maka semakin tinggi biaya operasional yang dikeluarkan oleh suatu bank. Hal tersebut akan berakibat pada berkurangnya laba sebelum pajak yang pada akhirnya akan menurunkan laba atau profitabilitas bank yang bersangkutan.

Menurut Dendawijaya (2005) rasio biaya operasional digunakan untuk mengukur tingkat efisiensi dan kemampuan bank dalam melakukan kegiatan operasinya. Semakin besar rasio operasional, menandakan semakin kecil tingkat efisiensi operasional bank dan sebaliknya. Kansil (2017) dalam penelitiannya risiko operasional yang diukur dengan BOPO (Belanja Operasional terhadap Pendapatan Operasional) menunjukan bahwa berpengaruh negatif signifikan terhadap kinerja keuangan.

\section{Pengaruh Positif Risiko Suku Bunga (BI Rate) Terhadap Kinerja Keuangan (ROE).}

Berdasarkan hasil uji di atas, dapat diperoleh nilai koefisien sebesar 0,590102 dan nilai t-hitung lebih kecil dari t-tabel 2,308358 (2,308358 > 1,675). Artinya risiko suku bunga (BI Rate) berpengaruh positif signifikan terhadap kinerja keuangan sektor perbankan periode 2013-2017. Hipotesis keempat yang mengatakan risiko suku bunga (BI Rate) berpengaruh positif signifikan terhadap kinerja keuangan sektor perbankan periode 2013-2017 diterima.

Risiko suku bunga adalah risiko akibat perubahan harga instrumen keuangan dari posisi trading book atau akibat perubahan nilai ekonomis dari posisi banking book yang disebabkan oleh perubahan suku bunga. Ketika suku bunga meningkat, maka profitabilitas bank juga meningkat, hal ini ditunjukan dengan melihat suku bunga simpanan yang meningkat, maka akan menjadi daya tarik masyarakat untuk menabungkan atau menginvestasikan dananya. Mankiw (2007) mengatakan return on equity dipengaruhi oleh aktivitas makro ekonomi suatu negara. Suku Bunga Bank Indonesia yang merupakan bagian dari instrumen moneter Bank Indonesia selaku Bank Sentral dalam mengendalikan laju tingkat inflasi di Indonesia. Suku Bunga Bank Indonesia merupakan ukuran biaya modal yang harus dikeluarkan oleh pelaku usaha atau suatu perusahaan untuk menggunakan dana dari para investor.

Naiknya tingkat suku bunga dapat menarik perhatian investor untuk menyimpan uangnya di bank. Ketika banyak investor yang menyimpan uangnya di bank, menandakan kinerja keuangan perusahaan dinilai baik oleh para investor. Fathunnida (2017) dalam penelitiannya menunjukan bahwa variabel tingkat suku bunga (BI Rate) 
berpengaruh positif signifikan terhadap kinerja keuangan.

\section{Risiko Likuiditas (LDR), Risiko} Kredit (NPL), Risiko Operasional (BOPO) dan Risiko Suku Bunga (BI Rate) Berpengaruh Secara Simultan Terhadap Kinerja Keuangan (ROE).

Berdasarkan hasil uji secara simultan, diperoleh nilai f-hitung sebesar 79,09323, yang mana lebih besar dari nilai f-tabel yaitu 2,79. Artinya variabel risiko likuiditas, risiko kredit, risiko operasional dan risiko suku bunga secara simultan berpengaruh signifikan terhadap kinerja keuangan. Hipotesis kelima yang mengatakan risiko likuiditas, risiko kredit, risiko operasional dan risiko suku bunga secara simultan berpengaruh signifikan terhadap kinerja keuangan pada sektor perbankan periode 2013-2017 diterima.

\section{KESIMPULAN DAN SARAN}

\section{Kesimpulan}

Berdasarkan hasil dari pengujian pengaruh penerapan manajemen risiko terhadap kinerja keuangan sektor perbankan pada Bank Umum Swasta Nasional (BUSN) devisa yang terdaftar di BEI tahun 2013-2017, maka dapat diambil kesimpulan sebagai berikut:

1. Hasil penelitian secara parsial bahwa risiko likuiditas (LDR) berpengaruh negatif tidak signifikan terhadap kinerja keuangan.

2. Hasil penelitian secara parsial bahwa risiko kredit (NPL) berpengaruh negatif signifikan terhadap kinerja keuangan.

3. Hasil penelitian secara parsial bahwa risiko operasional (BOPO) berpengaruh negatif signifikan terhadap kinerja keuangan.

4. Hasil penelitian secara parsial bahwa risiko suku bunga (BI 7-Day Repo Rate atau BI Rate) berpengaruh positif signifikan terhadap kinerja keuangan.
5. Hasil penelitian secara simultan bahwa risiko likuiditas, risiko kredit, risiko operasional dan risiko suku bunga berpengaruh signifikan terhadap kinerja keuangan.

\section{Saran}

1. Penelitian selanjutnya dapat menambahkan variabel lain yang memungkinkan memiliki pengaruh terhadap kinerja keuangan perbankan. Misalnya risiko strategis, risiko reputasi dan risiko kepatuhan.

2. Penelitian selanjutnya dapat menambahkan periode pengamatan untuk memperoleh hasil penelitian yang lebih baik.

3. Peneliti menyarankan untuk investor dan calon investor lebih memperhatikan risiko yang memiliki pengaruh terhadap kinerja keuangan suatu perbankan sebagai bahan pertimbangan untuk mengambil keputusan.

\section{DAFTAR PUSTAKA}

Aldrigde, John. E., dan Siswanto Sutojo. (2008). Good Corporate Governance. Jakarta: Damat Mulia Pustaka.

Attar, Dini, dkk. (2014). Pengaruh Penerapan Manajemen Risiko Terhadap Kinerja Keuangan Perbankan yang Terdaftar di Bursa Efek Indonesia. Jurnal Akuntansi Panscasarjana Universitas Kuala Banda Aceh Vol. 3 No.1.

Dendawijaya, Lukman. (2005). Manajemen Perbankan. Bogor: Ghalia Indonesia.

Dendawijaya, Lukman. (2009). Manajemen Perbankan. Edisi 2. Bogor: Ghalia Indonesia.

Fahmi, Irham. (2014). Manajemen Risiko. Bandung: Alfabeta. 
Fathunnida, dkk. (2017). Dampak makro ekonomi terhadap Profitabilitas Bank. Jurnal Manajemen Fakultas Ekonomi dan Bisnis Universitas Mulawarman Samarinda Vol. 9 No.1.

Fitri, Aulia Diani. (2016). Pengaruh Risiko Pasar, Risiko Kredit dan Risiko Operasional Terhadap Kinerja Keuangan Perbankan. E-Jurnal Fakultas Ekonomi Universitas Negeri Padang.

Hanafi, Mamduh M. (2016). Manajemen Risiko. Edisi 3. Yogyakarta: UPP Sekolah Tinggi Ilmu Manajemen YKPN.

Kansil, Deyby dkk. (2017). Pengaruh Risiko Perbankan Terhadap Kinerja Keuangan Tahun 2013-2015. Jurnal EMBA Vol. 5 No. 3.

Kasmir. (2013). Bank dan Lembaga Keuanga Lainnya. Jakarta: Rajawali.

Kasmir. (2013). Analisis Laporan Keuangan. Jakarta: Rajawali.

Kusuma, Desta Rizky dan Deny Ismanto. (2012). Modul Praktikum E-views.

Mankiw, N. Gregory. (2007). Makroekonomi. Jakarta: Penerbit Erlangga.

Otoritas Jasa Keuangan: Surat Edaran No.14/SEOJK.03/2017

Peraturan Bank Indonesia No.19/6/PBI/2017

Rustam, Bambang Rianto. (2017). Manajemen Risiko: Prinsip, Penerapan dan Penelitian. Jakarta: Salemba Empat.

Sofyan. (2016). Pengaruh CAR, BOPO, NPL dan LDR Terhadap ROE Pada
Bank Devisa. Jurnal Ilmu dan Riset Manajemen.

Sugiyono. (2016). Metode Penelitian Kuantitatif, Kualitatif dan Kombinasi (mixed Methods). Bandung : CV. Alfabeta.

Undang-Undang RI Nomor 10 Tahun 1998 Tentang Perbankan

Wijarjono, Agus. (2013). Ekonometrika Pengantar dan Aplikasinya disertai Panduan E-Views (Edisi 4). Yogyakarta: UPP STIM YKPN 